\title{
The influence of recycled concrete aggregate on the properties of concrete
}

\author{
Nisreen Mohammed ${ }^{1}$, Kaiss Sarsam ${ }^{1}$ and Mazin Hussien ${ }^{1}$ \\ ${ }^{1}$ Building and Construction Engineering Department, University of Technology, Baghdad, Iraq
}

\begin{abstract}
Use of Recycled Coarse Aggregate (RCA) in concrete can be described in terms of environmental protection and economy. This paper deals with the mechanical properties of concrete compressive strength, splitting tensile strength, modulus of elasticity, and modulus of rupture. Three kinds of concrete mixtures were tested, concrete made with Natural Coarse Aggregate (NCA) as a control concrete and two types of concrete made with recycled coarse aggregate (50\% and $100 \%$ replacement level of coarse recycled aggregate). These kinds of concrete were made with different targets of compressive strength of concrete f 'c (35MPa) and (70 MPa). Fifty specimens were tested of the fresh and hardened properties of concrete. The waste concrete from laboratory test cubes was crushed to produce the Recycled Coarse Aggregate used in recycled concrete. A comparative between the experimental results of the properties for fresh and hardened concrete is presented in the paper. Recycled aggregate concrete (RCA) had a satisfactory performance despite the replacement ratios. It was found using the size of Recycled Coarse Aggregate (RCA) of (5-14) $\mathrm{mm}$ has quite similar in performance with the same size of Natural Coarse Aggregate (NCA), it is necessary to use high quality of recycled concrete (with low levels of impurities). Recycled aggregate as an alternative to natural aggregates -seems quite successful.
\end{abstract}

\section{Introduction}

USE of recycled aggregate (RA) in concrete is to be considered as a trend for environment protection and to support the economy. The application of recycled aggregate as being used in construction since the end of World War II, by demolished concrete pavement as recycled aggregate in stabilizing the base course for road construction (Olorusongo, F.T., 1999) [1]. These are many advantages of using recycle aggregate in construction industry such as environmental friendliness and economic sense. The wastes from demolition and construction works represent a big problem as it gets

accumulated gradually and increases with time, so the recycled aggregate the perfect solution for this problem. The sustainable concrete construction is to be considered as a main strategy for the construction industry. It is important to reduce energy consumption that is associated with carbon dioxide and gas emissions, which cause " greenhouse effect", Portland cement production releases huge amount of carbon dioxide and other greenhouse gases (GHG) in the atmosphere (Malhotra and Bilodeau, 1999) [2]. The construction waste produced from building demolition alone is estimated to be 123 million tons per year in the USA [3]. In Iraq the amount of the construction waste amounts to $1,111,788$ tons/year (the Iraqi environmental ministry). Since the materials waste is increases with the growing population and increasing urban cities, an investigation and research on the usage of waste construction materials is significant. Therefore, many research and analysis have been made on recycled aggregate. Also the recycled aggregate is less expensive and easy to obtain as compared with normal aggregate. In order to reduce the usage of natural aggregate, recycled aggregate can be used as the replacement materials (N.Sivakumar et al. 2014) [4].

\section{Literature Review}

Many researches are involved interests in previously used processing of demolished concrete, the mixture design including the physical and the mechanical properties in addition to the durability process. Most of these researches are widely being studied and tested such as Hansen [5,6] and ACI 555 reported [7], which showed that some Characteristics of Recycled Aggregate Concrete (RAC) may be normally lesser than the ordinary concrete, but in spite of that, it gives satisfactory result for some practical usages related to Civil Engineering. The key mechanical properties for (RAC) are represented by compressive strength, flexural strengths, modulus of elasticity, and the tensile strength of such concrete. In present years, many investigations have also been performed for the Mechanical properties of (RAC). Bairagi and Kishore [8], found a comparable ratio of strain-stress relationship for recycled aggregate concrete to that of normal concrete. Poon and Lam [9], showed that a 
particular amount of the mortar and cement paste from original concrete when smashed concrete is crushed and remains stuck to the stone particles of the recycled aggregate, thus the attached mortar is the main cause for lower quality of (RCA) compared to (NCA).. The density of (RCA) is decreased to $10 \%$ compared with the density of (NCA). (Rahal, 2007) [10], Refer to the range of water absorption of coarse (RCA) which reaches from $3.5 \%$ to $9.2 \%$. (Lopez-Gayarre et al., 2009) [11], Showed that the resistance of the abrasion (Los Angeles test) for (RCA) is lowered up to $70 \%$ as compared that for (NCA).

(Sanchez de et a. 2004) [12].

Noticed that the recycled coarse aggregate has lesser specific gravity and bulk density than the natural coarse aggregate. (Yang, K.H. et al.,2008) [13]. The main conclusions that can be drawn are the concrete with recycled coarse aggregate decrease up to $(25 \%, 10 \%$, $45 \%$ ) for compressive strength, flexural tensile strength and modulus of elasticity, respectively as compared to those with concrete containing natural coarse aggregate. (BS 8500-1, 2006) [14], explain Recycled Aggregate (RA) is defined as the generic term for aggregate result from the reprocessing of inorganic material previously used in construction. American Concrete Institute (ACI 318) [15], specifies that aggregates must meet the requirements of ASTM C33 [16]. Neither (ACI 301) [17] nor (ACI 318) included specific provisions on using RCA in concrete. Guidance on use of recycled materials in concrete is mainly provided by ACI Technical Committee 555[18], in the report "Demolition and Reuse of Hardened Concrete".

\section{Experimental work}

The principal objective of this research work, the recycled aggregate collected from the waste concrete of laboratory test cubes (the debris have been selected, cleaned and sieved in laboratory). This paper deals with the study of compressive and splitting tensile strengths as well as modulus of elasticity, and modulus of rupture. Five types of concrete mixes were casted and made with f 'c (35 and 70) $\mathrm{MPa}$, three for natural coarse aggregate (NCA) and two types of concrete made with recycled coarse aggregate (RCA) (50\% and $100 \%$ replacement level of coarse recycled aggregate). Fifty specimens were tested of the fresh and hardened properties of concrete.

\subsection{Material testing and Mix design}

\subsubsection{Cement}

The cement used in casting all the specimens in this study is Ordinary Portland Cement (OPC) type (I), well-known (Mass), Al-Sulaimaniya, Iraq. It was tested according to (Iraqi Standard Specification (I.Q.S No.5:1984) [19] and complied with (ASTM C150-02), [20] physical properties of cement in Table (1).
Table 1. Physical Properties of Cement

\begin{tabular}{|c|c|c|}
\hline Physical Properties & $\begin{array}{l}\text { Test } \\
\text { result }\end{array}$ & $\begin{array}{l}\text { Limits of } \\
\text { Iraqi } \\
\text { specification } \\
\text { No.5:1984 }\end{array}$ \\
\hline $\begin{array}{l}\text { Fineness }\left(\mathrm{cm}^{2} / \mathrm{g}\right) \text { by } \\
\text { Blaine method }\end{array}$ & 2632 & $>2300$ \\
\hline $\begin{array}{l}\text { Setting time (Vicat's } \\
\text { method) Initial setting } \\
\text { (min) Final } \\
\text { setting(min) }\end{array}$ & $\begin{array}{l}168 \\
245\end{array}$ & $\begin{array}{l}>45 \mathrm{~min} \\
<10 \mathrm{hrs}\end{array}$ \\
\hline $\begin{array}{l}\text { Compressive strength } \\
\text { for cement mortar } \\
\text { cube }(70.7) \mathrm{mm} \text { at, } \\
\mathrm{MPa} \\
\begin{array}{l}3 \text { days } \\
7 \text { days }\end{array}\end{array}$ & $\begin{array}{l}16.9 \\
24.5\end{array}$ & $\begin{array}{l}>15 \\
>23\end{array}$ \\
\hline $\begin{array}{l}\text { Soundness using Auto } \\
\text { clave } \%\end{array}$ & 0.2 & $<0.8$ \\
\hline
\end{tabular}

\subsubsection{Fine aggregate}

Natural sand from AL-Ukhaider region, Iraq, was used in this study. The fine aggregate grading was checked according to the I.Q.S (No. 45/1984) [21] Zone 2, and the British Standard Specification (B.S. 882:1992) [22]. Table (2) shows the physical properties of fine aggregate.

Table 2. Physical properties of fine aggregate

\begin{tabular}{|l|l|l|}
\hline $\begin{array}{l}\text { Physical } \\
\text { properties }\end{array}$ & Test result & $\begin{array}{l}\text { Limit of Iraqi } \\
\text { specification } \\
\text { No.45:1984 }\end{array}$ \\
\hline Specific gravity & 2.63 & - \\
\hline Sulfate content & $0.39 \%$ & $0.5 \%$ (max) \\
\hline Absorption & $1.75 \%$ & - \\
\hline Fineness modulus & 2.9 & - \\
\hline
\end{tabular}

\subsubsection{Coarse aggregate}

The maximum size of $(14 \mathrm{~mm})$ crushed natural gravel was used in this work as saturated surface dry (SSD) condition, the limits confirm to the I.Q.S (NO.45/1984) and specifications (ASTM C33-02) [23]. Table (3) shows the physical properties of the natural coarse aggregate according to Iraqi specification (No.45:1984) [22].

Table 3. Physical properties of Natural Coarse Aggregate

\begin{tabular}{|l|l|l|}
\hline $\begin{array}{l}\text { Physical } \\
\text { properties }\end{array}$ & $\begin{array}{l}\text { Test } \\
\text { result }\end{array}$ & $\begin{array}{l}\text { Limit of Iraqi } \\
\text { specification } \\
\text { No.45:1984 }\end{array}$ \\
\hline Specific gravity & 2.65 & - \\
\hline Absorption & $0.7 \%$ & - \\
\hline Crushed value & $15 \%$ & - \\
\hline Sulfate content & $0.06 \%$ & $0.1 \%$ (max) \\
\hline
\end{tabular}

\subsubsection{Recycled coarse aggregate}

Recycled coarse aggregate used in this study was obtained by crushing waste concrete test cubes used in previous works to get small pieces with maximum size $(14 \mathrm{~mm})$ of recycled aggregate (the debris have been selected, cleaned and sieved in laboratory). The sieve analysis of recycled coarse aggregate (RCA) according 
to the I.Q.S (No.45: 1984), and (ASTM C33-02) specifications. Table (4) shows the physical properties of Recycled Coarse Aggregate according to the I.Q.S (No.45:1984). The recycled coarse aggregate is shown in Figure 1.

Table 4. Physical properties of recycled coarse aggregate

\begin{tabular}{|l|l|l|}
\hline $\begin{array}{l}\text { Physical } \\
\text { properties }\end{array}$ & Test result & $\begin{array}{l}\text { Limit of Iraqi } \\
\text { specification } \\
\text { No.45:1984 }\end{array}$ \\
\hline Specific gravity & 2.4 & - \\
\hline Absorption & $3.6 \%$ & - \\
\hline Crushed value & $21 \%$ & - \\
\hline Sulfate content & $0.08 \%$ & $0.1 \%(\max )$ \\
\hline
\end{tabular}

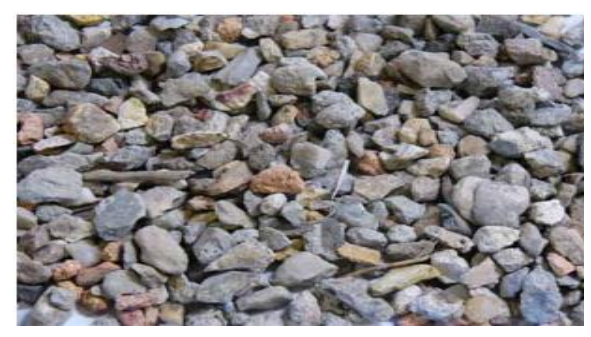

Fig. 1. Recycled Coarse Aggregate

Table 5. Details of mixes

\begin{tabular}{|c|c|c|c|c|c|c|c|c|c|}
\hline \multirow{2}{*}{ Specimen } & \multirow{2}{*}{$\begin{array}{l}\text { Compressiv } \\
\text { e strength }\end{array}$} & \multirow{2}{*}{ Code } & \multirow{2}{*}{$\begin{array}{c}\text { Cement } \\
\mathrm{kg} / \mathrm{m}^{3}\end{array}$} & \multirow{2}{*}{$\begin{array}{l}\text { Sand } \\
\mathrm{kg} / \mathrm{m}^{3}\end{array}$} & \multicolumn{2}{|c|}{ Gravel $\left(\mathrm{kg} / \mathrm{m}^{3}\right)$} & \multirow{2}{*}{$\begin{array}{l}\text { Water } \\
1 / \mathrm{m}^{3}\end{array}$} & \multirow{2}{*}{$\underset{1 / \mathrm{m}^{3}}{\text { Glenium51 }}$} & \multirow{2}{*}{$\begin{array}{l}\text { Silica } \\
\text { fume } \\
\mathrm{kg} / \mathrm{m}^{3}\end{array}$} \\
\hline & & & & & Normal & Recycled & & & \\
\hline \multirow{3}{*}{ N35 } & \multirow{3}{*}{$35 \mathrm{MPa}$} & 35 N.C & 400 & 745 & 990 & - & 185 & 1.6 & - \\
\hline & & $50 \%$ R35 & 400 & 745 & 495 & 495 & 185 & 2.1 & - \\
\hline & & $100 \% \mathrm{R} 35$ & 400 & 745 & - & 990 & 185 & 2.5 & - \\
\hline \multirow{3}{*}{$\mathrm{H} 70$} & \multirow{3}{*}{$70 \mathrm{MPa}$} & 70 N.C & 450 & 750 & 1000 & - & 126 & 12.5 & 50 \\
\hline & & $50 \%$ R70 & 450 & 750 & 500 & 500 & 126 & 16 & 50 \\
\hline & & $100 \% \mathrm{R} 70$ & 450 & 750 & - & 1000 & 126 & 19 & 50 \\
\hline
\end{tabular}

Table 6. Casting Samples of Concrete Properties

\begin{tabular}{|l|c|c|c|}
\hline Concrete Properties & Sample & No. of samples & Total No. of Samples \\
\hline Compressive strength & Cubs $(150 \times 150 \times 150) \mathrm{mm}$ & 6 & 18 \\
\hline Modulus of rupture & Prism $(100 \times 100 \times 500) \mathrm{mm}$ & 3 & 9 \\
\hline Modulus of elasticity & $\begin{array}{c}\text { Cylinder } 150 \mathrm{~mm} \text { diameter } \times 300 \mathrm{~mm} \\
\text { height }\end{array}$ & 3 & 9 \\
\hline Splitting tensile strength & $\begin{array}{c}\text { Cylinder } 150 \mathrm{~mm} \text { diameter } \times 300 \mathrm{~mm} \\
\text { height }\end{array}$ & 3 & 9 \\
\hline
\end{tabular}

Note: The average values were obtained from the three measured values. 


\subsubsection{Water}

Normal potable water has been used in the process of mixing concrete for the production and curing of concrete.

\subsubsection{Admixtures (Superplasticizer)}

A superplasticizer used throughout this work was "Glenium 51" with nominal dosage of ( 0.5 liter per 100 $\mathrm{kg}$ of cement) as recommended by the manufacturer. This material was classified as type (A) and (F) in ASTM C494-05 [24]. The main virtue of (Glenium 51) is its ability of water reduction and keeping the workability of fresh concrete. Superplasticizers increase the early and ultimate compressive strength. The relative density of Glenium $51\left(1.1 \mathrm{~g} / \mathrm{cm}^{3} @ 20^{\circ} \mathrm{C}\right)$ and $\mathrm{pH}=(6.6)$.

\subsubsection{Mix Design}

Designing the Mix as in many experimental mixes have beenmade in accordance with the standards of the ACI 211.1-97[25]. Concrete mixture has been designed in order to realize cylinder strength of $(35 \mathrm{MPa}$, and 70 $\mathrm{MPa}$ ) at (28) days (obtain the normal, and high strength concrete respectively) Mixture details are given in Table (5). It was found that the used mixture produces good workability as well as uniform mixing of concrete without segregation, the slump test was carried out according to (ASTM C143-00) [26]. The slump was approximately $( \pm 100 \mathrm{~mm})$.

\subsection{Casting, curing and testing work}

Fifty specimens were tested the fresh and hardened properties through the pouring of casting, curing and testing work for each mix and for each type of coarse aggregate. six cubes of $(150 \times 150 \times 150) \mathrm{mm}$ in size were used according to (BS 1881:part116) [27], for testing the compressive strength of concrete at 7 days and 28 days for three types of concrete mixes for NCR and two replacement level of coarse recycled aggregate $(50 \%$ and $100 \%)$. Each of the three cylinders of (150 $\mathrm{mm}$ diameter and $300 \mathrm{~mm}$ height) of each type of mix was used to find the split tensile strength of concrete at 28 days according to (BS 1881: part 117) [28] and the modulus of elasticity of concrete at 28 days as recommended by (ASTM C469-02a)[29]. Moreover, three prisms size $(100 \mathrm{~mm} \times 100 \mathrm{~mm} \times 500 \mathrm{~mm})$ were cast using steel molds to determine the modulus of rupture at 28 days according to (ASTM C78-02) [30] for each type. The samples were kept at room temperature for 24 hours. After that, the samples were demolded and put in water for treatment. After (7) and (28) days, they were removed from the water to air dry environment for (24) hours and then tested in accordance with the standard specifications to determine the concrete properties of hardened concrete, the following standard samples were cast as illustrated in Table (6).

\section{Results and discussion 4.1 Compressive strength}

The Compressive strength is most important property of the hardened concrete. According to (BS 1881:part116), standard cubes of $(150 \times 150 \times 150 \mathrm{~mm})$ were used, they were poured and tested to compute $\left(f^{\prime}{ }_{c}\right)$ at 7 days and 28 days of age. A hydraulic universal machine with $3000 \mathrm{kN}$ capacity was used in test. The results are presented in Table (7).

Table 7. Concrete Compressive Strength of Specimens

\begin{tabular}{|c|c|c|c|}
\hline Specimen & Code & $\begin{array}{c}f^{\prime}{ }_{\mathrm{c}}(\mathrm{MPa}-7 \\
\text { days })\end{array}$ & $\begin{array}{c}f^{\prime} \mathrm{c}(\mathrm{MPa}-28 \\
\text { days })\end{array}$ \\
\hline \multirow{3}{*}{ N35 } & $35 \mathrm{~N} . \mathrm{C}$ & 29 & 36 \\
\cline { 2 - 4 } & $50 \%$ R35 & 28 & 35 \\
\cline { 2 - 4 } & $100 \%$ R35 & 26 & 33 \\
\hline \multirow{3}{*}{ H70 } & 70 N.C & 60 & 70 \\
\cline { 2 - 4 } & $50 \%$ R70 & 56 & 68 \\
\cline { 2 - 4 } & $100 \%$ R70 & 50 & 60 \\
\hline
\end{tabular}

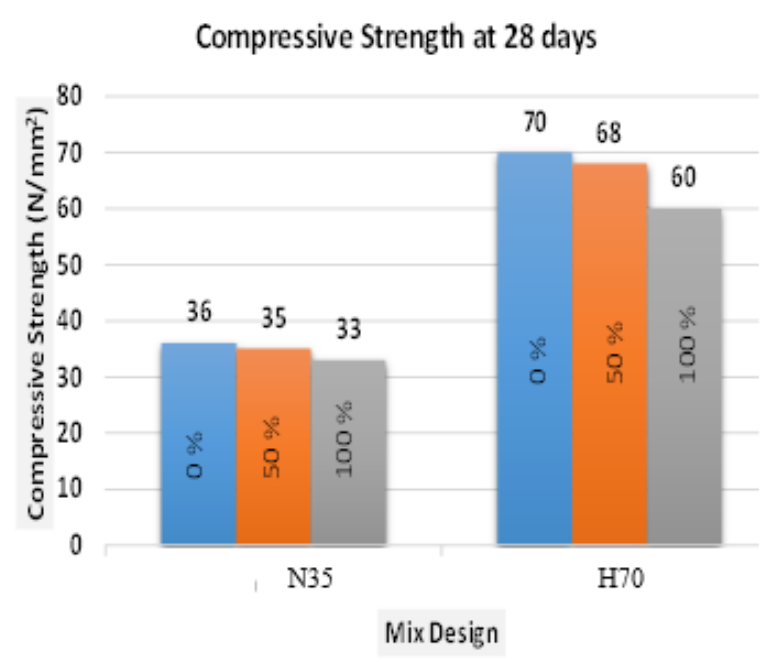

Figure (2): Compressive strength at 28 days

The results show that the lowest compressive strength was achieved for concrete specimens containings high percentage of recycled aggregate. In general, the $f^{\prime}$ co concrete at 7 days was $80 \%$ of these at 28 days. Fig.(2) shows that the $f^{\prime}{ }_{c}$ for $50 \%$ contain of RCA at 28 days has dropped around $2.8 \%$ for both types. Even upto $100 \%$ replacement of recycled aggregate, the compressive strength was reduced only to a maximum of $8.34 \%$ for type $(35 \mathrm{MPa})$ and $14.29 \%$ to type (70 $\mathrm{MPa}$ ), with respect to that of control concrete. The compressive strength of the concrete specimens for $50 \%$ recycled aggregate is $(35) \mathrm{N} / \mathrm{mm}^{2}$, which meets the target strength of (35)N/mm $\mathrm{mm}^{2}$ to the first kind from the results, it is clear that there is a possibility to use $50 \%$ recycled coarse aggregate in applications like normal concrete. 


\subsection{Splitting tensile strength}

According to (BS 1881: part 117), a (150*300) mm has been used for the splitting tensile test. The cylinders are moist cured in water and tested at age of 28 days by a compressive load. The split tensile test indicates a decreasing trend of split tensile strength at 28 days of curing, when the percentage of recycled aggregate is increased. Table (8) represents the tensile strength values for mixes at 28 days.

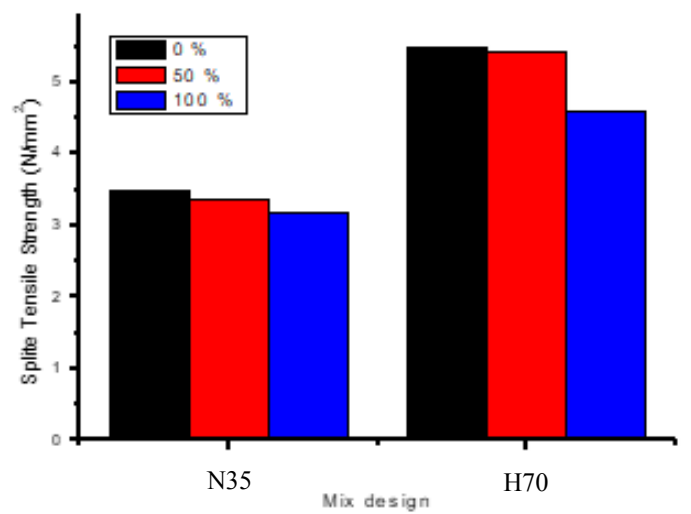

Figure (3): Splitting tensile strength at 28 days

Flexural Strength of Concrete at 28 Days

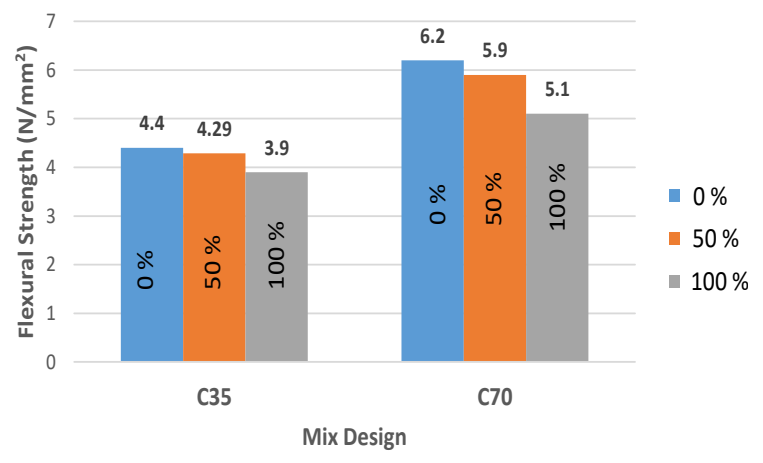

Figure (4): Flexural strength of concrete at 28 days

Figure (3) shows the splitting tensile strength for two kinds of mixes (N35 and H70). The lowest tensile strength was achieved by concrete specimen with $100 \%$ recycled coarse aggregate, for both kinds but acceptable through the difference does not exceed $(8.86 \%)$ for first type and $(16.2 \%)$ to second kind, between $0 \%$ replacement and $100 \%$ of recycled coarse aggregate, However, the concrete specimen with the $50 \%$ recycled aggregate has the maximum tensile strength. It just drops $(3.7 \%)$, which still remainsed $(96.3 \%)$ when compared to $0 \%$ recycled aggregate concrete specimen for first type, and (1.3\%) only drops with the second type of mix design.

Table 8. Splitting tensile strength at 28 days

\begin{tabular}{|c|c|c|}
\hline \multirow{3}{*}{ Specimen } & Code & $\begin{array}{l}\text { Split tensile } \\
\text { strength -MPa }- \\
\text { at 28 days }\end{array}$ \\
\hline \multirow{3}{*}{ N35 } & 35N.C & 3.5 \\
\cline { 2 - 3 } & $50 \%$ R35 & 3.37 \\
\cline { 2 - 3 } & $100 \%$ R35 & 3.19 \\
\hline \multirow{3}{*}{ H70 } & 70 N.C & 5.5 \\
\cline { 2 - 3 } & $50 \%$ R70 & 5.43 \\
\cline { 2 - 3 } & $100 \%$ R70 & 4.61 \\
\hline
\end{tabular}

\subsection{Flexural strength}

Using $(100 * 100 * 400) \mathrm{mm}$ prism to express the modulus of rupture by two point load of hydraulic machine with loading capacity of $(50 \mathrm{KN})$ mentioned in (ASTM C78-02). The flexural strength capability for the RAC and NAC mixes during 28 days of curing has been shown in Table (9). The concrete samples with $100 \%$ of replacement recycled aggregate have the lowest amount of flexural strength compared to specimens with $50 \%$ of the recycled aggregate concrete. Fig.(4) shows that there is a reduction in flexural strength about $2.3 \%$ and $11.4 \%$ to the concrete samples with $50 \%$ and $100 \%$ coarse aggregates, respectively for first mix and the drop is $4.8 \%$ and $17.75 \%$ to the concrete specimens with $50 \%$ and $100 \%$ replacement, respectively with the second kind of mix design.

Table 9. Flexural strength of concrete at 28 days

\begin{tabular}{|c|c|c|}
\hline \multirow{2}{*}{ Specimen } & Code & $\begin{array}{c}\text { Flexural strength } \\
-\mathrm{MPa}-\text { at 28 days }\end{array}$ \\
\hline \multirow{3}{*}{ N35 } & $35 \mathrm{~N} . \mathrm{C}$ & 4.4 \\
\cline { 2 - 3 } & $50 \% \mathrm{R} 35$ & 4.29 \\
\cline { 2 - 3 } & $100 \% \mathrm{R} 35$ & 3.9 \\
\hline \multirow{3}{*}{ H70 } & $70 \mathrm{~N} . \mathrm{C}$ & 6.2 \\
\cline { 2 - 3 } & $50 \% \mathrm{R} 70$ & 5.9 \\
\cline { 2 - 3 } & $100 \% \mathrm{R} 70$ & 5.1 \\
\hline
\end{tabular}

\subsection{Modulus of elasticity}

According to (ASTM C469-02a) the chord-modulus method has been used to find the modulus of elasticity. The modulus of elasticity can be calculated from the stress-strain diagram. The chord-modulus is the slope for the linear part of curve between the point in which the strain will be 0.00005 , and the point where stress equals $40 \%$ of the ultimate stress. All cylinders sample are tested at age of (28 days). The results of mixes are given in Table (10). The specimen of NCR has the 
highest value of modulus of elasticity compared with the specimens of $100 \%$ recycled aggregate. From the experimental results, the modulus of elasticity of full NCA was 31.378 GPa to specimen (N35) while the full RCA (100\% replacement level) was $27.208 \mathrm{GPa}$ as indicated in Fig. (5). It is a loss of $4.17 \mathrm{GPa}$, so the percentage of variation is $13.3 \%$ between $0 \%$ and $100 \%$ recycled coarse aggregate. For the second specimen (H70) the modulus of elasticity of NCR specimens was $42.03 \mathrm{GPa}$, while the modulus of elasticity of $100 \%$ recycled coarse aggregate specimens was $36.566 \mathrm{Gpa}$, so, the drop percentage was $13 \%$.

Table 10. Modulus of Elasticity of Concrete at 28 days strength

\begin{tabular}{|c|c|c|}
\hline \multirow{2}{*}{ Specimen } & Code & $\begin{array}{c}\text { Modulus of } \\
\text { Elasticity -GPa }- \\
\text { at } 28 \text { days }\end{array}$ \\
\hline \multirow{3}{*}{ N35 } & 35 N.C & 31.378 \\
\cline { 2 - 3 } & $50 \%$ R35 & 29.496 \\
\cline { 2 - 3 } & $100 \%$ R35 & 27.208 \\
\hline \multirow{3}{*}{ H70 } & 70 N.C & 42.03 \\
\cline { 2 - 3 } & $50 \%$ R70 & 39.852 \\
\cline { 2 - 3 } & $100 \%$ R70 & 36.566 \\
\hline
\end{tabular}

Modulus of Elasticity of Concrete at 28 Days

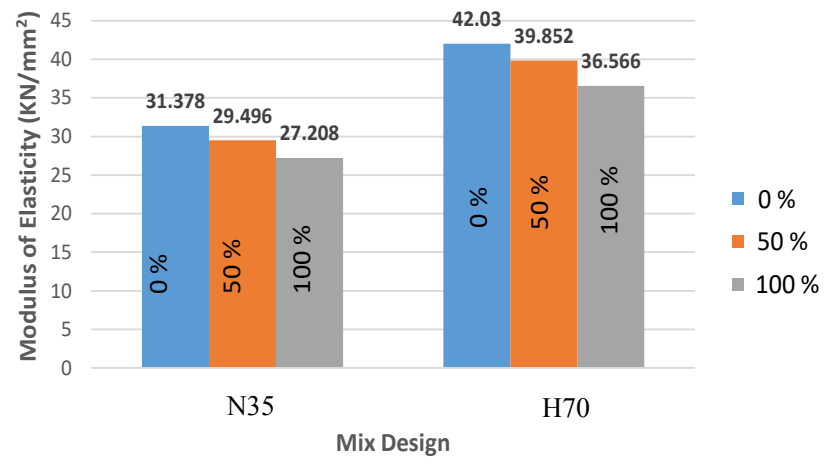

Figure (5): Modulus of Elasticity of Concrete at 28 days

\section{Conclusions}

This paper deals with the experimental tests of fresh and hardened Properties of recycled aggregate concrete. According to the results mentioned in this paper, there are some of the assumptions listed below.

1- The percentage of RCA Water absorption is more than the NCA level, because the older mortar stays adhered to the aggregate surface which leads to lessening the strengths.
2- The values of compressive strength to RCA and NCA for both mixing (N35 and H70) and two kinds of replacement aggregate $(50 \%$, and $100 \%)$ is clearly being noticed the RCA is lower than NCA, so, the strength of concrete decreases whenever the percentage of RCA increases.

3- Tensile stress of RC specimens showed about $8.86 \%$ reduction compared to that of $\mathrm{NC}$ specimens for first type (N35) and $16.2 \%$ for the second type (H70).

4- Test results showed that the flexural strength of the recycled aggregate concrete is found to be lower than the natural aggregate byabout $11.4 \%$ in the first type (N35) and $17.75 \%$ in the second kind (H70).

5- For the modulus of elasticity results the values decrease by about $13 \%$ by replacing $100 \%$ of recycled aggregate.

6- Based on the test results, it is recommended that the RCA can be replaced with natural aggregate $50 \%$ is sufficient than the replacement $100 \%$. The replacement RCA for $100 \%$ which need more investigate with high strength concrete so the designing engineering should take into account the decrease of strength when using recycled aggregate concrete.

7- The main trends detected specify that RCA can be used in high strength concrete mixes, if the engineering characteristics are consistent with acceptable compressive strength, flexural strength and modulus of elasticity.

8- There is a necessity to specify and identify new standards for recycled aggregates that can be used effectively under different conditions.

9- With the adoption of the developed recycling systems, it is possible to recycle concrete waste to lead to high efficiency in reducing both the cost and the environmental impact.

\section{References}

1- Olorusongo, F.T. (1999). Proceeding of the International Seminar on Exploiting Wastes in Concrete held at the University of Dundee, Scotland, UK on 7 September 1999, pp. 163-170.

2- Malhotra VM, Bilodeau In: Mehta PK, editor. Proc int symp on 'Concrete technology for sustainable development in the twenty-first century'. New Delhi (India): Radha Press; 1999. pp. 43-64.

3-Transportation Applications of Recycled Concrete Aggregate-FHWA State of the Practice National Review 2004; U.S. Department of Transportation Federal Highway Administration: Washington, DC, USA, 2004; pp. 1-47. 
4-N.Sivakumar, S.Muthukumar, V.Sivakumar,

D.Gowtham, V.Muthuraj. , International Journal of Engineering And Science Vol.4, Issue 01 (January 2014), PP. 27-36.

5-T.C. Hansen, second state-of-the-art report, developments from 1945-1985, Mater. Struct. 19 (111) (1986) 201- 246.

6- Hansen, T.C., Ed.; Taylor and Francis, Oxfordshire, UK, 1992; pp. 316.

7- ACI Committee 555, Removal and reuse of hardened concrete, ACI Mater. J. 99 (3) (2002) 300-325

8- N.K. Bairagi, R. KishoreResour. Conserv. Recycl. 9 (3) (1993) 109- 126

9- Poon, C.S., Lam, C.S., 2008. Cement and Concrete Composites 30 (4), 283-289.

10- Rahal, K., 2007, Building and Environment 42 (1), 407-415.

11-Lopez-Gayarre, F., Serna, P., Domingo-Cabo, A., Serrano-Lepez, M.A., Lopez-Colina,C., 2009. Waste Management 29 (12), 3022-3028.

12-Sanchez de Juan, M.; Gutierrez, P.A. In Proceeding of the International RILEM Conference: The Use of Recycled Materials in Building and Structures, Barcelona, Spain, 8-11 November 2004; pp. 545-553.

13- Yang, K.H.; Chung, H.S.; Ashour, A. , ACI Mater. J. 2008, 3, 289-296.

14- BS 8500-1 (2006), Volume 2, Section 3, Part 9 BA 92/07. (BRE Digest 433), Volume 2, Section 3, Part 9 BA $92 / 07$.

15- ACI Committee 318, "Building Code Requirements for Structural Concrete", ACI 318-11, Committee 318 Report, American Concrete Institute, Farmington Hills, Michigan, 2011, 443 pages.

16- ASTM C 33 - 11a, "Standard Specification for Concrete Aggregates", Annual Book of ASTM Standards, American Society for Testing and Materials, West Conshohocken, Pennsylvania, USA, 2011, 11 pages

17- ACI Committee 301, "Specifications for Structural Concrete", ACI 301-10, Committee 301 Report, American Concrete Institute, Farmington Hills, Michigan, 2010, 81 pages.

18- ACI Committee 555, "Removal and Reuse of Hardened Concrete," ACI 555R-01, Committee 555 Report, American Concrete Institute, Farmington Hills, MI, 2001, 26 pages.
19- Central Organization for Standardization and Quality Control; "Iraqi Standard Specification for the Portland Cement" ;IQS (5) ,1984, Baghdad, Iraq.

20- ASTM Designation C150-02 "Standard specification for Portland cement", 2002 Annual Book of ASTM Standards, American Society for Testing and Material, Philadelphia, Pennsylvania, Section 4, Vol. (4.02), pp 89-93, 2002.

21- Iraqi Specification No. 45, "Natural Sources for Gravel that is Used in Concrete and Construction", Baghdad, 1984.

22-British Standard Specification (B.S.882:1992)

Aggregates from Natural Sources for concrete", 1992.

23- American Society of Testing and Material (ASTM), "Standard Specification for Concrete Aggregates", ASTM C33-02, West Conshohocken, PA, 2002.

24- Standard Specification for Chemical Admixtures for Concrete. ASTM-C494-05, American Society for Testing and Material, 2005.

25- ACI 211.1-97, (Re-approved 1997), "Standard practice for selecting proportions for normal, heavy weight and mass concrete", ACI Manual of Concrete Practice, American Concrete Institute, Detroit, 1997.

26- ASTM Designation C143-00 "Standard specification for test method for slump of Portland cement concrete", 2000 Annual Book of ASTM Standards, American Society for Testing and Material, Philadelphia, Pennsylvania, Section 4, Vol. (4.02), pp $1-3,2000$.

27- BS 1881: Part 116:1983, "Method for Determination of Compressive Strength of Concrete Cubes".

28- BS 1881: Part 117:1983, "Method for Determination of Tensile Splitting Strength".

29- ASTM Designation C469-02a, "Static Modulus of Elasticity and Poisson's Ratio of Concrete in Compression" 2002 Annual Book of ASTM Standards, American Society for Testing and Materials, Section 4, Vol.04.02, pp.236-239.

30- ASTM Designation C78-02, "Flexural Strength of Concrete". 